\title{
FENOMENA RUMAH SEDERHANA DI KOTA MEDAN
}

\author{
Shanty Silitonga, ST., MT. ${ }^{(1)}$, Polin DR Naibaho, ST.,MT ${ }^{(2)}$ \\ (1) Staff Pengajar, Prodi Arsitektur, Fakultas Teknik, Universitas Katolik Santo Thomas Sumatera Utara \\ Email: shanty.silitonga@gmail.com \\ (2) Staff Pengajar, Prodi Arsitektur, Fakultas Teknik, Universitas Katolik Santo Thomas Sumatera Utara \\ Email: polin_naibaho@ust.ac.id
}

\begin{abstract}
Affordable houses bloom in Medan due to high demand. Although labeled affordable, there is some contradiction. The primary task of this paper is to compile the various conditions and issues that related to affordable houses in suburban of Medan and to develop its conceptual framework of housing mismatch through literature review gathered. This research uses descriptive qualitative research method. The study found that price factor is the most influencing factor (pull factor) for people to buy the house, followed by affordable installment and attractive building facades.It concluded that there are mismatches between the type of housing unit offered and the group desired by low and middle-income people, location and unhealthy physical conditions.
\end{abstract}

Keywords: House, Affordable, Pull Factors, Mismatch

\begin{abstract}
Abstrak
Pembangunan Rumah Sederhana di kota Medan berkembang pesat. Walaupun diberi label Sederhana, namun terdapat beberapa hal yang tidak sesuai pada kenyataannya. Tujuan utama dari penelitian ini adalah untuk mengumpulkan kondisi-kondisi aktual di lapangan dan membahas isu-isu terkait keberadaan Rumah Sederhana yang berkembang pesat di pinggiran kota Medan dan penelitian ini juga akan menghasilkan kerangka konseptual tentang bagaimana banyak terjadi inkonsistensi dalam kepemilikan Rumah Sederhana di kota Medan; antara harapan pembeli dan kenyataan di lapangan. Penelitian ini menggunakan metode penelitian kualitatif. Penelitian sebelumnya menyimpulkan bahwa Harga rumah merupakan Faktor Penarik yang paling mempengaruhi masyarakat untuk membeli rumah, faktor lain yang mempengaruhi adalah faktor cicilan rumah yang sederhana dan faktor fasad bangunan yang menarik. Penelitian ini menemukan bahwa terdapat inkonsistensi antara harapan pembeli dengan kenyataan dilapangan terhadap type rumah, lokasi rumah yang jauh dari tempat kerja dan kondisi fisik/kesehatan rumah yang tergolong tidak sehat.
\end{abstract}

\section{Kata kunci: Rumah, Sederhana, Faktor Penarik, Inkonsistensi}

\section{Pendahuluan}

Penelitian ini adalah studi lanjutan, di dalam penelitian awal ditemukan bahwa sebagian besar rumah sederhana di pinggiran kota Medan tidak sehat (Silitonga, 2017). Semua rumah sederhana di lokasi penelitian pada umumnya berbentuk rumah deret. Dalam penelitian awal ditemukan bahwa sampel penelitian telah memenuhi standar minimum Keselamatan dan Keamanan yang dikeluarkan oleh Pemerintah, akan tetapi perlu mempertimbangkan lokasi yang rawan gempa. Standar tersebut masih belum memasukkan kriteria ramah gempa. Standar ini juga kurang sesuai untuk rumah petak dimana kualitas rumah tidak sesuai dengan standar kesehata sebagai contoh lubang ventilasi memiliki dimensi yang sangat kecil. Meskipun dikategorikan tidak sehat, rumah-rumah tersebut terjual habis. Dengan latar belakang inilah, penelitian yang kedua dilakukan untuk mencari tahu apa saja faktor penarik yang membuat masyarakat membeli rumah-rumah tersebut.

\section{Faktor-Faktor Penarik (Pull Factors) Masyarakat Membeli Rumah}

Rumah adalah kebutuhan utama manusia dan sekarang telah bertambah nilainya menjadi bentuk investasi. Saat ini terdapat banyak skema kepemilikan rumah yang dapat memberikan beragam pilihan 
bagi masyarakat untuk membeli rumah tersebut (Hashim, et. Al, 2012), salah satu skenarionya adalah pemerintah memberikan subsidi untuk masyarakat kelas menengah ke bawah. Subsidi diberikan untuk perumahan murah. Perumahan murah telah diakui sebagai gagasan yang sangat berguna bagi masyarakat dengan pendapatan menengah kebawah sehingga memungkinkan mereka untuk mengakses rumah yang layak. Sebuah studi menyatakan bahwa $60 \%$ orang yang tinggal di perumahan murah berasal dari keluarga berpenghasilan rendah dengan banyak anak (Currie \& Yelowitz, 2000).

Ada banyak faktor yang mempengaruhi seseorang dalam membeli rumah. Eckert (1990) menyebutkan beberapa faktor yang sangat penting dan mempengaruhi permintaan pasar perumahan, yang pertama adalah faktor ekonomi; pendapatan, suku bunga, kebijakan pinjaman, harga sewa dan harga rumah. Semakin besar penghasilan seseorang, kecenderungan untuk memilih rumah juga akan berubah. Faktor kedua adalah faktor sosial, yaitu kepadatan penduduk, ukuran keluarga, pendidikan, tingkat kejahatan dan distribusi usia. Faktor ketiga adalah pemerintah, yang meliputi layanan pemerintah kota dan tingkat pajak publik. Faktor terakhir adalah faktor lingkungan, perubahan faktor lingkungan yang mempengaruhi permintaan perumahan adalah topografi, bentuk tanah, kondisi tanah dan fasilitas seperti: parkir, pusat perbelanjaan, sekolah, tempat ibadah, peluang kerja, transportasi dan sebagainya.

Lebih jauh Firdaus (1997) menyatakan bahwa permintaan konsumen akan rumah dipengaruhi oleh empat faktor. Faktor pertama adalah lokasi, faktor kedua adalah pertumbuhan populasi. Setiap populasi meningkat baik secara alami maupun non-alami akan meningkatkan permintaan akan perumahan. Faktor ketiga adalah kemudahan mendapatkan pinjaman. Permintaan perumahan juga dipengaruhi oleh kebijakan pemerintah dan lembaga keuangan seperti bank. Kemudahan pendanaan seperti suku bunga rendah dan periode pembayaran kredit yang diperpanjang dapat memudahkan konsumen dalam membeli rumah. Faktor keempat adalah fasilitas dan infrastruktur publik. Fasilitas di sini termasuk fasilitas umum dan fasilitas sosial, termasuk infrastruktur, fasilitas pendidikan, kesehatan, agama, transportasi, dan lainnya. Semakin beragam dan semakin dekat fasilitas ini, semakin tinggi nilai sebuah rumah.

Fasilitas adalah faktor yang paling diinginkan, terutama fasilitas untuk anak-anak dan remaja. Karena tingginya jumlah anak yang tinggal di rumah yang sederhana, fasilitas yang memadai yang mendukung kebutuhan mereka yang berkembang harus dipertimbangkan. Aktivitas fisik di antara anakanak berkontribusi pada kesehatan fisik dan mental, dan itu memengaruhi perkembangan mereka secara keseluruhan. Ini menunjukkan bahwa lingkungan fisik di perumahan murah akan membatasi kebebasan anak-anak untuk bermain di luar, sehingga berkontribusi terhadap beberapa masalah kesehatan dan penyakit anak-anak di antara anak-anak (van Loon et al., 2014; Vandivere et al., 2006). Keamanan yang buruk, kepadatan yang berlebihan, fasilitas yang tidak memadai dan hubungan lingkungan yang buruk akan mengurangi aktivitas fisik anak-anak dan meningkatkan waktu yang dihabiskan untuk menetap yang dapat menyebabkan masalah kesehatan dan sosial di masa depan. Fasilitas lain yang diminati pembeli adalah fasilitas untuk kaum muda (Omara et all, 2016) dan taman (Aulia, 2016). Fasilitas lain yang diinginkan adalah jalur pejalan kaki dan kendaraan. Lingkungan saat ini dirancang lebih ramah terhadap kendaraan daripada ramah orang yang dapat menyebabkan peningkatan kecelakaan lalu lintas.

Penelitian ini menggunakan teori Li (2010) yaitu intra-city housing alternatives. Dia menyatakan bahwa ada 8 faktor yang mempengaruhi seseorang membeli rumah; jaringan transportasi, infrastruktur lingkungan, lingkungan masyarakat dan atribut perumahan.

\subsection{Rumah Sederhana?}

Arti rumah yang sederhana adalah rumah dengan harga yang terjangkau oleh masyarakat ekonomi yang lebih rendah. Dua sampel (sampel 1, 3 pada Gambar.1.1) adalah rumah yang sederhana dengan kisaran harga Rp. 135.000 .000 hingga Rp. 165.000.000, luas bangunan $36 \mathrm{~m} 2$ dan luas tanah sekitar $91 \mathrm{~m} 2$. Harga ini sudah merupakan harga bersih yang harus dibayar pemilik rumah. Harga rumah telah dikurangi oleh subsidi pemerintah, lokasi di pinggiran kota Medan. Sedangkan sampel 3 (gbr.1.1) memiliki harga jual Rp. 244.000 .000 dengan luas bangunan $37 \mathrm{~m} 2$ dan luas tanah $78 \mathrm{~m} 2$, perumahan ini tidak disubsidi, lokasinya juga berada di pinggiran kota Medan. Jumlah rata-rata orang yang hidup dalam sampel 3 berasal dari kelas menengah; hampir setiap rumah memiliki kendaraan roda empat. 


\section{Metodologi}

Penelitian ini menggunakan metode campuran metode kuantitatif dan kualitatif. Ditahap awal dilakukan studi literatur, untuk mengumpulkan berbagai variabel yang telah diidentifikasi dari berbagai penelitian sebelumnya. Untuk mendapatkan informasi yang dibutuhkan, penelitian ini menggunakan kuesioner dan teknik wawancara dengan model bola salju untuk setiap lokasi perumahan. Tahap selanjutnya adalah memproses informasi yang dikumpulkan, mengelompokkannya berdasarkan tema-tema tertentu. Penelitian ini mengambil 3 lokasi perumahan sebagai sampel. Pilihan ini didasarkan pada karakteristik, waktu konstruksi, dan lokasi yang berbeda antara satu sama lain. Total jumlah responden yang berkontribusi pada penelitian ini adalah 72 orang yang dipilih secara acak di setiap lokasi perumahan. Responden dikategorikan berdasarkan tingkat pendapatan mereka. Lokasi penelitian terletak di pinggiran kota Medan, ketiganya berada di Kabupaten Deli Serdang (Gbr. 1). Semua sampel adalah pemilik rumah tipe $36-37$.

\subsection{Metode Analisa Data}

Penelitian ini memakai metodologi analisis deskriptif. Dengan metode ini, tidak perlu melakukan uji validitas dan reliabilitas pada kuesioner. Faktor-faktor dihitung dengan menganalisis frekuensinya.

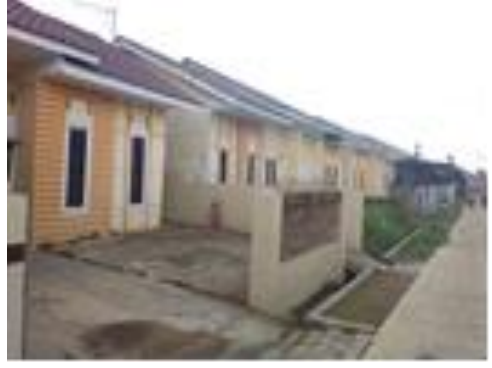

(1)

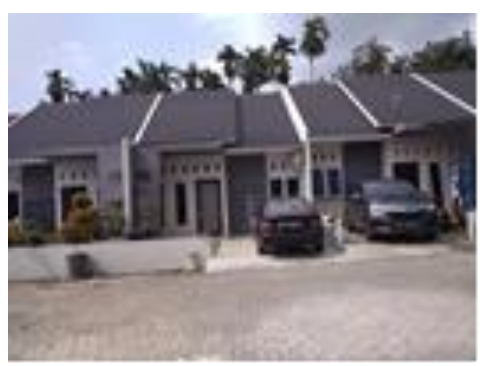

(2)

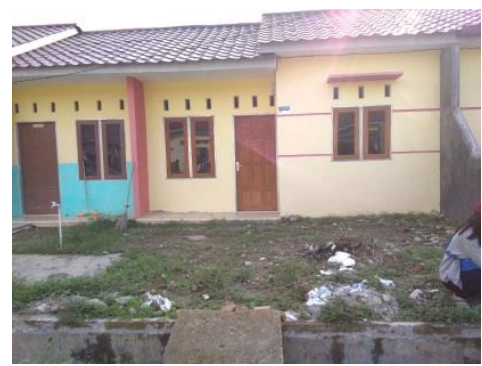

(3)

Gambar 1.1 Tiga Sampel

Sumber: Peneliti, 2018

\section{Analisa}

\section{Karakteristik pembeli rumah yang sederhana di Pinggiran Kota Medan}

Pemilik rumah pada umumnya adalah karyawan swasta, guru, dan pengusaha kecil. Penghasilan bulanan mereka berkisar antara Rp2.000.000 hingga Rp5.000.000. Cicilan bulanan rumah berkisar antara Rp.700.000 hingga Rp.850.000, per bulan. Pemilik rumah rata-rata adalah keluarga muda dengan rentang usia antara 30-50 tahun, rata-rata memiliki 1-3 anak.

\section{Faktor yang Mempengaruhi Masyarakat Membeli Rumah}

Faktor yang paling berpengaruh adalah tipe rumah, sesuai dengan kebutuhan yaitu rumah 36$37 \mathrm{~m} 2$, memiliki dua kamar tidur dengan satu kamar mandi dan dapur sederhana di belakang. Berdasarkan hasil wawancara, rata-rata responden adalah keluarga muda yang memiliki 1-3 anak, mereka merasa bahwa tipe 36 cukup untuk memenuhi kebutuhan ruang keluarga mereka. Faktor kedua yang mempengaruhi adalah angsuran. Semua responden memiliki rumah dengan sistem kredit, angsurannya berkisar dari Rp. 700.000 - Rp. 850.000, - di mana mereka merasa harganya sangat sederhana. Program pemerintah yang memberikan subsidi dirasakan sangat membantu. Faktor lain yang menjadi faktor penarik untuk membeli rumah adalah infrastruktur drainase lingkungan yang baik, fasad bangunan yang menarik, jalan lingkungan dan kedekatan dengan lokasi perumahan dengan pekerjaan atau sekolah anakanak mereka. Faktor yang tidak mempengaruhi minat responden adalah berbagai fasilitas lingkungan 
seperti fasilitas pendidikan, fasilitas kesehatan, fasilitas olahraga, fasilitas email dan ruang terbuka hijau. Semua fasilitas ini tidak tersedia di semua sampel.

\section{Fenomena Rumah Sederhana di Pinggiran Kota Medan}

Berdasarkan teori, ada beberapa faktor penarik yang mempengaruhi seseorang untuk membeli rumah, salah satunya adalah fasilitas. Ini tidak ditemukan dalam ketiga sampel penelitian ini, mereka tidak memiliki fasilitas yang memadai. Tidak ada ruang terbuka atau taman, tidak ada tempat olahraga, tidak ada fasilitas pendidikan, tidak ada fasilitas kesehatan, tidak ada fasilitas komersial dan beberapa bahkan tidak memiliki cukup lampu jalan (Gbr.1.3). Tetapi semua sampel terjual habis. Hal yang paling mengejutkan terjadi pada sampel no.1 yang memiliki jumlah unit terbanyak, terdapat beberapa tahap pengembangan tetapi tidak dilengkapi dengan berbagai fasilitas tersebut. Berdasarkan hasil wawancara, faktor harga dan cicilan yang sederhana adalah faktor yang paling kuat, bahkan ada banyak pemilik rumah yang memiliki tempat kerja yang sangat jauh dari rumah mereka.

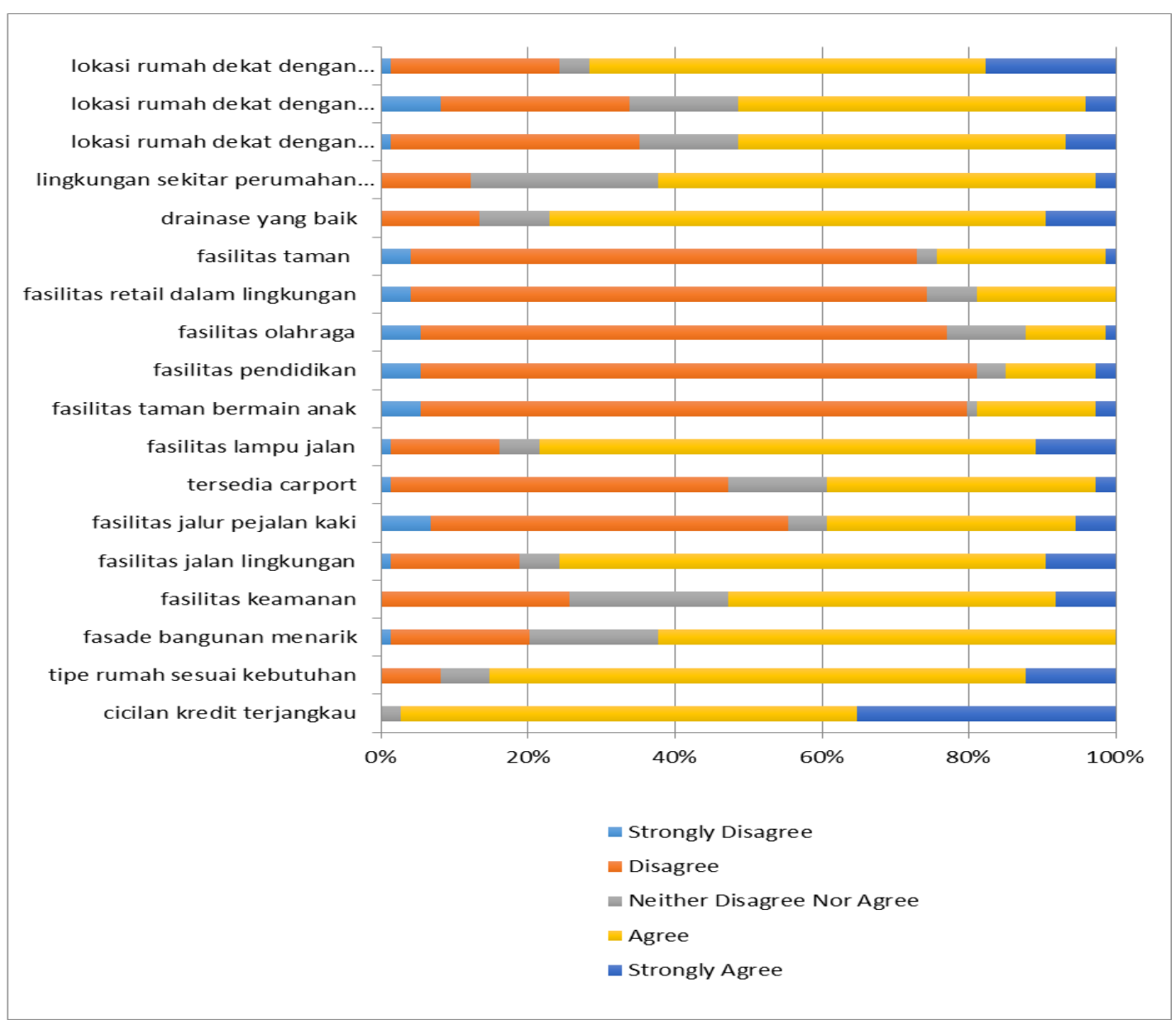

Tabel 1.2 Hasil Proses Data

Sumber: Peneliti, 2018

Berdasarkan hasil kuisioner ditemukan bahwa responden bahkan harus melakukan perjalanan selama lebih dari 1 jam untuk mencapai tempat kerja. Mereka rela pergi kerja pagi-pagi dan pulang hampir malam. Memiliki rumah adalah kebutuhan yang sangat mereka butuhkan. 


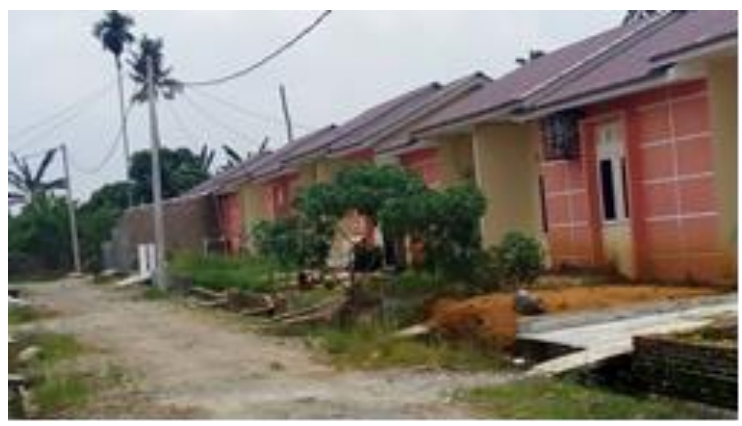

Gambar 1.3 Sampel 1

Sumber: Peneliti, 2018

Berdasarkan wawancara, sebagian besar pemilik rumah bekerja sebagai pegawai swasta, guru, pedagang kecil, bahkan pengemudi dan pengemudi becak. Selama pengamatan, peneliti melihat bahwa ada beberapa pemilik rumah dari komunitas kelas menengah ke atas. Ini bertentangan dengan tujuan pengadaan rumah sederhana yang ditujukan untuk masyarakat ekonomi bawah. Ini ditemukan di ketiga lokasi sampel. Penelitian ini juga temuan yang sama dengan penelitian sebelumnya. Ditemukan bahwa rumah unit tidak sehat. Lubang ventilasi masih sangat sedikit (Gbr.1.4); semua sampel memiliki lubang ventilasi di bawah 5 persen sebagaimana ditentukan oleh rumah sehat dengan harga sederhana. Jika ini berjalan maka mau tidak mau, penghuni akan dipaksa untuk memakai AC, dan itu sangat memberatkan karena penghuni adalah masyarakat berpenghasilan rendah.

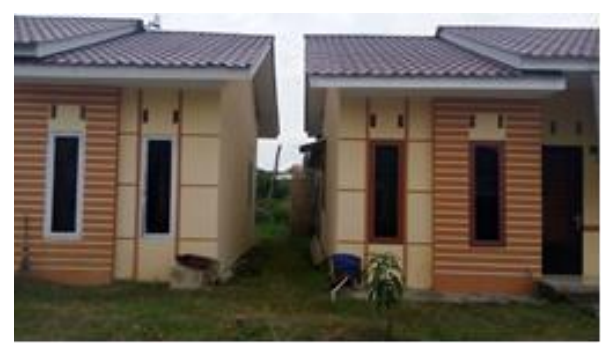

Gambar 1.4 Sampel 1

Sumber: Peneliti, 2018

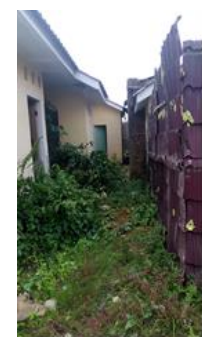

Gambar 1.5 Sampel 1

Sumber: Peneliti, 2018

Dan ini dibuktikan dengan hasil wawancara yang menyatakan bahwa sebagian besar pemilik rumah merasa bahwa rumah mereka panas dan pengap terutama pada siang hari. Bahkan ada ruang sempit di antara rumah-rumah yang memiliki dimensi sekitar $20 \mathrm{~cm}$ yang tidak dapat digunakan untuk apa pun dan bahkan menjadi tempat untuk pertumbuhan semak dan tempat bersarangnya tikus (Gbr.1.5). Ini sangat disesalkan karena kesehatan dan kenyamanan termal adalah persyaratan wajib di hunian, termasuk yang sederhana.

\section{Kesimpulan}

Rumah yang sederhana adalah kebutuhan vital masyarakat kita, terutama bagi masyarakat ekonomi bawah. Penelitian ini menemukan bahwa teori tentang faktor penarik seseorang membeli rumah tidak valid dalam tiga sampel rumah sederhana di Medan. Meskipun mereka tidak memiliki fasilitas yang memadai, tidak memiliki infrastruktur yang baik dan bahkan dalam kategori tidak sehat, tetapi rumah itu laris manis. Bahkan posisi rumah yang sangat jauh dari tempat kerja, itu bukan faktor pencegah. Harga perumahan yang sederhana dengan skema cicilan yang mudah dan sederhana adalah faktor yang paling kuat. 


\section{Ucapan Terima Kasih}

Para penulis dengan penuh rasa terima kasih mengakui bahwa makalah ini adalah salah satu hasil dari penelitian yang didukung oleh Kementerian Riset dan Teknologi dan Republik Pendidikan Tinggi Republik Indonesia. Dukungan tersebut berasal dari hibah penelitian Penelitian Dosen Pemula tahun fiskal 2018 dengan judul studi Faktor-Faktor Penarik (Faktor Penarik) Masyarakat Membeli Rumah Sederhana di Pinggiran Kota Medan.

\section{Daftar Pustaka}

Aulia, N.A. (2013). Residential Satisfaction of Middle Income Population: Medan City. Procedia - Social and Behavioral Sciences, 105, $674-683$

Currie, J; Yelowitz, A. (2000). Are public hosuing good for kids?. Journal of Public Economics, 75, 99-124

Firdaus, A. (1997) "Permintaan dan Penawaran Perumahan", Valuestate, Vol. 007, Jakarta.

Hashim, A.Z; Samikon, S.A; Ismail, F; Ismail, Z. (2012). Managing Facilities on Malaysian Low- cost Public Residential for Sustainable Adaptation. Procedia - Social and Behavioral Sciences, 168, $52-60$.

Li, L. (2010). Housing Choice in an Affluent Shanghai - Decision. Modern Economy, 9-17.

Omara, K. A; Omarb, D; Othmanc S; Yusoffa, Z. M, (2016) Reviewing Youth Facility Requirements for Low-Cost Housing in Malaysia Procedia-Social and Behavioral Sciences, 222. 702-709.

Silitonga, S. (2017). To be an affordable healthy house case study Medan. IOP Conf. Ser.: Earth Environ. Sci. 126 012161.

Van Loon, PP. (2014). Sustainability and urban density a decision based design approach. Management and Innovation for a Sustainable Built Environment. Downloaded August, 25th 2018, from Tudelft Repository.

Vandivere, S; Elisabeth, C; Theokas, C; Cleveland, K; McNamara, N; Atienza, A. (2006 Tudelft Repository). How housing affects child well-being. Downloaded August, 25th 2018, from researchgate.net. 